\title{
The effect of an increased free fatty acid concentration on thermogenesis and substrate oxidation in obese and lean men.
}

Citation for published version (APA):

Schiffelers, S. L. H., Saris, W. H. M., \& van Baak, M. A. (2001). The effect of an increased free fatty acid concentration on thermogenesis and substrate oxidation in obese and lean men. International Journal of Obesity, 25, 33-38. https://doi.org/10.1038/sj.ijo.0801528

Document status and date:

Published: 01/01/2001

DOI:

10.1038/sj.ijo.0801528

Document Version:

Publisher's PDF, also known as Version of record

Please check the document version of this publication:

- A submitted manuscript is the version of the article upon submission and before peer-review. There can be important differences between the submitted version and the official published version of record.

People interested in the research are advised to contact the author for the final version of the publication, or visit the DOI to the publisher's website.

- The final author version and the galley proof are versions of the publication after peer review.

- The final published version features the final layout of the paper including the volume, issue and page numbers.

Link to publication

\footnotetext{
General rights rights.

- You may freely distribute the URL identifying the publication in the public portal. please follow below link for the End User Agreement:

www.umlib.nl/taverne-license

Take down policy

If you believe that this document breaches copyright please contact us at:

repository@maastrichtuniversity.nl

providing details and we will investigate your claim.
}

Copyright and moral rights for the publications made accessible in the public portal are retained by the authors and/or other copyright owners and it is a condition of accessing publications that users recognise and abide by the legal requirements associated with these

- Users may download and print one copy of any publication from the public portal for the purpose of private study or research.

- You may not further distribute the material or use it for any profit-making activity or commercial gain

If the publication is distributed under the terms of Article 25fa of the Dutch Copyright Act, indicated by the "Taverne" license above, 


\title{
The effect of an increased free fatty acid concentration on thermogenesis and substrate oxidation in obese and lean men
}

\author{
SLH Schiffelers $^{1 *}$, WHM Saris ${ }^{1}$ and MA van Baak $^{1}$ \\ ${ }^{1}$ Nutrition Toxicology and Environment Research Institute Maastricht, Department of Human Biology, Maastricht University, \\ Maastricht, The Netherlands
}

OBJECTIVE: To examine whether a certain increase in plasma free fatty acid (FFA) concentration leads to similar increases in lipid oxidation and energy expenditure in obese and lean men.

DESIGN: The study protocol consisted of a $30 \mathrm{~min}$ baseline period after which subjects received an i.v. bolus of 1000 IE heparin. Then consecutive infusions of $4.9,9.8$ and $19.6 \mu \mathrm{l} / \mathrm{kg}$ fat-free mass (FFM) $\cdot \mathrm{min}$ of a lipid heparin mixture were started, each infusion for $30 \mathrm{~min}$.

SUBJECTS: Eleven obese and 13 lean men with a mean body mass index (BMI) of $34.2 \pm 1.0$ ( \pm s.e.m.) and $23.9 \pm 0.5 \mathrm{~kg} / \mathrm{m}^{2}$ and age $46.0 \pm 1.0$ and $42.6 \pm 1.5 \mathrm{y}$, respectively.

MEASUREMENTS: Energy expenditure, respiratory exchange ratio (RER) and carbohydrate and lipid oxidation were continuously measured by indirect calorimetry. At the end of each infusion period, a blood sample was taken for FFA, glycerol, insulin, $\beta$-hydroxybutyrate, noradrenaline and adrenaline determination.

RESULTS: At baseline, plasma FFA levels were comparable in both groups. Lipid heparin infusion increased plasma FFA concentration by $301 \pm 47 \mu \mathrm{mol} / \mathrm{l}$ and $332 \pm 27 \mu \mathrm{mol} / \mathrm{l}$ in obese and lean men. Energy expenditure increased similarly in obese and lean men ( $0.34 \pm 0.08$ vs $0.40 \pm 0.08 \mathrm{~kJ} / \mathrm{min}, \mathrm{NS})$ during lipid heparin infusion, whereas RER decreased similarly in both groups. Lipid oxidation rates were comparable at baseline and increased similarly in obese and lean men ( $19 \pm 5$ vs $13 \pm 4 \mathrm{mg} / \mathrm{min}, \mathrm{NS}$ ). Baseline plasma insulin levels were higher in the obese, but did not change during lipid heparin infusion. Plasma $\beta$-hydroxybutyrate concentrations were similar at baseline, but increased significantly less in the obese during lipid heparin infusion. Baseline noradrenaline and adrenaline concentrations did not differ significantly between groups. During lipid heparin infusion, plasma noradrenaline levels decreased significantly, but plasma adrenaline levels remained unchanged in both groups.

CONCLUSION: A certain increase in plasma FFA concentration leads to similar increases in lipid oxidation and energy expenditure in obese and lean men. The accumulation of fat in obese subjects may therefore be more likely to be due to a defect in adipose tissue lipolysis than a defect in lipid oxidation.

International Journal of Obesity (2001) 25, 33-38

Keywords: energy expenditure; lipid oxidation; obesity

\section{Introduction}

Energy expenditure increases after the ingestion or infusion of nutrients. Activation of the sympathetic nervous system (SNS) may, at least partly, contribute to this increase in

*Correspondence: SLH Schiffelers, Department of Human Biology, Maastricht University, PO Box 616, 6200 MD Maastricht, The Netherlands.

E-mail: s.schiffelers@hb.unimaas.nl

Received 8 October 1999; revised 24 July 2000;

accepted 20 September 2000 thermogenesis, ${ }^{1-3}$ although this finding is not consistent. ${ }^{4}$ Previous studies have shown that mainly $\beta_{1}$-and $\beta_{2}$-adrenoceptors are involved in sympathetically mediated thermogenesis. $^{5,6}$ During selective $\beta_{1}$-adrenergic stimulation, lipolysis, lipid oxidation and energy expenditure increase. ${ }^{7,8}$ Free fatty acids (FFA), needed for lipid oxidation, are released from the adipose tissue by stimulating its $\beta_{1}$-adrenoceptors. The increase in lipid oxidation and thermogenesis is assumed to be localized predominantly in skeletal muscle, ${ }^{9,10}$ but this tissue contains mainly $\beta_{2}$-adrenoceptors 
and presumably no $\beta_{1}$-adrenoceptors. ${ }^{11} \beta_{1}$-Adrenergic stimulation is therefore not likely to increase lipid oxidation by direct stimulation of skeletal muscle. Another possibility is that the availability of FFA in the blood may induce the increase in lipid oxidation and energy expenditure.

Furthermore, it is suggested that the thermogenic effect of food is reduced in obese subjects, although the results are inconsistent (for review see De Jonge et $a l^{12}$ ). A reduction in diet-induced thermogenesis in the obese might be explained by their reduced thermogenic response during SNS stimulation. ${ }^{13,14}$ Blaak et $a l^{10}$ showed that obese men have an impaired response of lipolysis and lipid oxidation during isoprenaline (non-selective $\beta$-agonist) infusion. If the availability of FFA in blood is a limiting factor for thermogenesis, the reduced lipolytic response in obese subjects could explain their reduced increases in lipid oxidation and thermogenesis.

On the other hand, thermogenesis and lipid oxidation could be impaired due to a defect in skeletal muscle metabolism. Colberg et al, ${ }^{15}$ showed that women with visceral obesity have reduced FFA utilization in muscle in the postabsorptive state. Furthermore, Colberg et $a l^{15}$ and Simoneau et $a 1^{16}$ found that obese women have a decreased oxidative capacity and increased glycolytic and anaerobic capacities of skeletal muscle. This may suggest that not FFA availability in blood, but rather the oxidative enzymes in skeletal muscle may be the limiting factor for the increase in lipid oxidation and thermogenesis.

The aim of the present study was to examine whether a certain increase in plasma FFA concentration leads to similar increases in lipid oxidation and energy expenditure in obese and lean men.

\section{Material and methods Subjects}

Eleven obese and 13 lean male volunteers participated in this study. The physical characteristics of the subjects are summarized in Table 1. All subjects were in good health as assessed by medical history and physical examination. Furthermore, both lean and obese subjects spent no more than $2 \mathrm{~h}$ a week in organized sports activities. The study protocol was reviewed and approved by the Ethics Commit-

Table 1 Subject characteristics

\begin{tabular}{lcc}
\hline Parameter & Obese men & Lean men \\
\hline Body weight $(\mathrm{kg})$ & $106.9 \pm 3.0^{*}$ & $75.2 \pm 2.9$ \\
Height $(\mathrm{m})$ & $1.77 \pm 0.02$ & $1.77 \pm 0.02$ \\
BMl $\left(\mathrm{kg} / \mathrm{m}^{2}\right)$ & $34.2 \pm 1.0^{*}$ & $23.9 \pm 0.5$ \\
Body fat $(\%)$ & $32.4 \pm 1.5^{\star}$ & $19.1 \pm 1.6$ \\
Fat-free mass $(\mathrm{kg})$ & $72.1 \pm 2.0^{*}$ & $60.7 \pm 2.1$ \\
Age $(\mathrm{y})$ & $46.0 \pm 1.0$ & $42.6 \pm 1.5$ \\
\hline
\end{tabular}

Results are mean $\pm 5 . e . m$. for 11 obese and 13 lean men. Unpaired t-test: $* p<0.001$. tee of Maastricht University and all subjects gave informed consent before participating in the study.

\section{Experimental design}

Subjects arrived at the laboratory at 8:00 am after an overnight fast. They came by car or by bus to minimize the amount of physical activity before the test. On arrival, one canula was inserted into a forearm vein to infuse a lipid heparin mixture and to sample venous blood. A second canula was inserted into a dorsal hand vein of the contralateral arm. This hand was kept in a hotbox with a temperature of $60^{\circ} \mathrm{C}$ for the sampling of arterialized blood. Ventilated hood measurements were started with the subject in supine position and room temperature was kept between 21 and $23^{\circ} \mathrm{C}$. After a $30 \mathrm{~min}$ baseline measurement, a bolus of 1000 IE heparin (Leo Pharmaceutical Products, Weesp, The Netherlands) was given, after which a continuous infusion of increasing doses of $4.9,9.8$ and $19.6 \mu \mathrm{l} / \mathrm{kg} \mathrm{FFM} \cdot$ min of a lipid heparin mixture (Intralipid $20 \%$, Pharmacia, Woerden, The Netherlands) (1000 IE heparin per $100 \mathrm{ml}$ Intralipid) was started, each dose given for $30 \mathrm{~min}$. At the end of each $30 \mathrm{~min}$ period, a blood sample was taken. In a pilot study, blood samples were taken after 20,25 and $30 \mathrm{~min}$ in each infusion period. The coefficient of variation $(\mathrm{CV})$ for plasma FFA concentration within each set of three samples was $5 \%$. Therefore, it was assumed that steady state was achieved in plasma FFA concentrations at the end of each infusion period.

\section{Clinical methods}

Body density was determined by hydrostatic weighing with simultaneous lung volume measurement (Volugraph 2000, Mijnhardt, Bunnik, The Netherlands). Body composition was calculated according to the equation of Siri. ${ }^{17}$ Whole body energy expenditure and respiratory exchange ratio (RER) were measured by an open-circuit ventilated hood system (Oxycon beta, Mijnhardt, Bunnik, The Netherlands). $\mathrm{O}_{2}$ consumption ( $\mathrm{CV}: 3.0 \%$ ) and $\mathrm{CO}_{2}$ production ( $\mathrm{CV}: 1.7 \%$ ) values were averaged over the last $10 \mathrm{~min}$ of each $30 \mathrm{~min}$ period. Energy expenditure was calculated according to the formula proposed by Weir. ${ }^{18}$ Carbohydrate and lipid oxidation rates were calculated as described by Ferrannini, ${ }^{19}$ assuming that protein oxidation accounted for $15 \%$ of total baseline energy expenditure and remained constant during the remainder of the test.

\section{Analytical methods}

Arterialized blood samples for the determination of FFA, glycerol, $\beta$-hydroxybutyrate and insulin were preserved in sodium-EDTA. Venous samples for the determination of noradrenaline and adrenaline were preserved in heparin plus glutathione $(1.5 \% \mathrm{w} / \mathrm{v})$. Blood samples were immediately centrifuged for $10 \mathrm{~min}$ at $3000 \mathrm{rpm}$ at $4^{\circ} \mathrm{C}$. Plasma was 
transferred into microtest tubes, rapidly frozen in liquid nitrogen and stored at $-70^{\circ} \mathrm{C}$ until further analysis. Plasma FFA concentrations were measured with the NEFA $C$ kit (99475409, WAKO, Neuss, Germany), plasma glycerol concentrations were measured with a glycerol kit (148270, Boehringer, Mannheim, Germany) and plasma $\beta$-hydroxybutyrate concentrations were measured according to the method of Moore et $a l_{,}{ }^{20}$ all on a Cobas-Fara centrifugal analyser (Roche Diagnostica, Basel, Switzerland). Plasma insulin concentrations were determined with a double-antibody radio immunoassay (Insulin RIA 100, Pharmacia, Uppsala, Sweden) and plasma noradrenaline and adrenaline concentrations by high performance liquid chromatography. ${ }^{21}$ Standard samples with known concentrations were included in each for quality control.

\section{Data analysis}

All data are presented as mean \pm s.e.m. Data for energy expenditure were adjusted for FFM for group comparison. ${ }^{22}$

The effect of lipid heparin infusion between obese and lean subjects was analysed with a two-way repeated measurements ANOVA. Post-hoc testing was done with Student's unpaired $t$-test. A $P$-value smaller than 0.05 was regarded as statistically significant.

\section{Results}

At baseline, plasma FFA and glycerol levels were similar in both groups. Lipid heparin infusion significantly increased FFA and glycerol concentrations (both $P<0.001$; Figure 1). These increases were not significantly different between groups (obese vs lean, $\triangle \mathrm{FFA}: 301 \pm 47$ vs $332 \pm 27 \mu \mathrm{mol} / \mathrm{l}$, NS; $\Delta$ glycerol: $170 \pm 8$ vs $151 \pm 11 \mu \mathrm{mol} / \mathrm{l}$, NS).

Baseline energy expenditure was significantly higher in the obese (Table 2). After adjustment for FFM, baseline energy expenditure was similar in normal weight and overweight men (Figure 2). Energy expenditure significantly increased $(P<0.001)$ during lipid heparin infusion. The increases were similar in both groups (obese $v$ s lean: $0.34 \pm 0.08$ vs $0.40 \pm 0.08 \mathrm{~kJ} / \mathrm{min}$, NS). RER was comparable between groups at baseline and decreased significantly

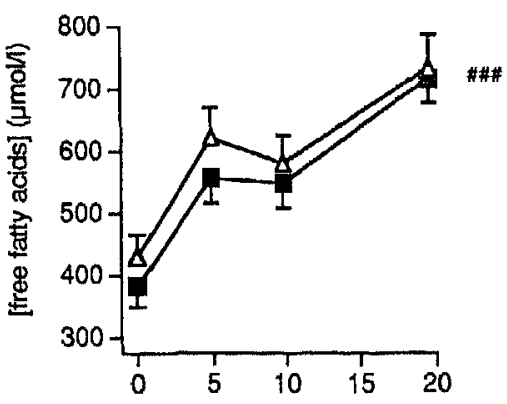

lipid heparin mixture ( $\mu / \mathrm{kgFFM} . \mathrm{min})$

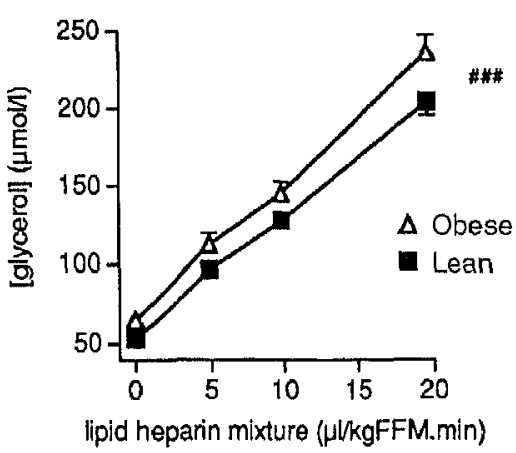

Figure 1 Plasma FFA and glycerol concentrations before and during the infusion of a lipid heparin mixture in 13 obese and 11 lean men. Values are mean $\pm 5 . e . m$. Repeated measurements ANOVA for treatment; \#\#\# $P<0.001$

$(P<0.001)$ during lipid heparin infusion (Figure 2). Lipid oxidation was similar in both groups at baseline. During lipid heparin infusion, lipid oxidation increased significantly $(P<0.001)$ and to a similar extent in obese and lean men ( $\Delta$ lipid oxidation: $19 \pm 5$ ws $13 \pm 4 \mathrm{mg} / \mathrm{min}$, NS, Table 2). Baseline carbohydrate oxidation did not differ between obese and lean men and significantly decreased $(P<0.05)$ during lipid heparin infusion. The decrease in carbohydrate oxidation was similar between groups (obese vs lean: $-29 \pm 12$ vs $-8 \pm 6 \mathrm{mg} / \mathrm{min}$, NS, Table 2). Expressed as percentage of total energy expenditure, lipid and carbohydrate oxidation were similar in both groups at baseline.

Table 2 Energy expenditure and lipid and carbohydrate oxidation rates at rest and during lipid heparin infusion in lean and obese men

\begin{tabular}{|c|c|c|c|c|c|c|}
\hline Parameter & Baseline & $\begin{array}{c}4.9 \mu \mathrm{l} / \\
\mathrm{kg}_{\mathrm{FFM}} \cdot \min \end{array}$ & $\begin{array}{c}9.8 \mu \mathrm{ll} / \\
\mathrm{kg}\end{array}$ & $\begin{array}{c}19.6 \mu \mathrm{l} / \\
\mathrm{kg} / \mathrm{FFM} \cdot \min \end{array}$ & $\begin{array}{c}\text { ANOVA } \\
\text { for treatment }\end{array}$ & $\begin{array}{l}\text { ANOVA for } \\
\text { group } \times \text { treatment }\end{array}$ \\
\hline Energy expenditure (k]/min) & & & & & $P<0.001$ & NS \\
\hline Obese & $5.97 \pm 0.19^{*}$ & $6.08 \pm 0.19^{*}$ & $6.07 \pm 0.20^{*}$ & $6.31 \pm 0.19^{*}$ & & \\
\hline Lean & $4.80 \pm 0.14$ & $4.91 \pm 0.17$ & $4.93 \pm 0.14$ & $5.20 \pm 0.14$ & & \\
\hline Lipid oxidation ( $\mathrm{mg} / \mathrm{min})$ & & & & & $P<0.001$ & NS \\
\hline Obese & $64 \pm 7$ & $73 \pm 9$ & $71 \pm 9$ & $83 \pm 6$ & & \\
\hline Lean & $54 \pm 3$ & $58 \pm 3$ & $56 \pm 3$ & $68 \pm 4$ & & \\
\hline Carbohydrate oxidation $(\mathrm{mg} / \mathrm{min})$ & & & & & $P<0.05$ & NS \\
\hline Obese & $150 \pm 20$ & $133 \pm 22$ & $138 \pm 23$ & $121 \pm 16$ & & \\
\hline Lean & $114 \pm 9$ & $113 \pm 10$ & $119 \pm 9$ & $106 \pm 10$ & & \\
\hline
\end{tabular}

Results are mean \pm s.e.m. for 11 obese and 13 lean men. Unpaired $t$-test: $* p<0.001$ obese vs lean. 

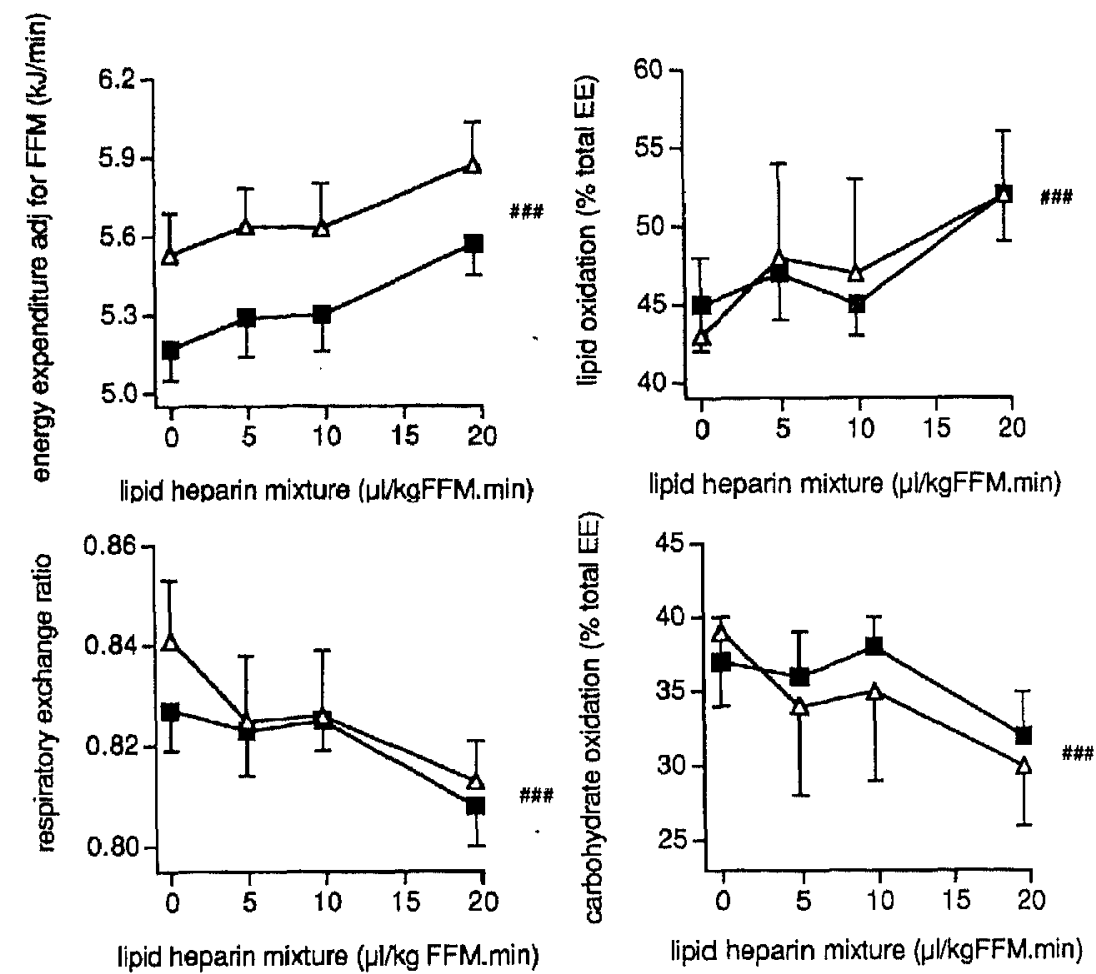

$\triangle$ Obese men

Lean men

Figure 2 Energy expenditure adjusted for FFM, respiratory exchange ratio and lipid and carbohydrate oxidation rates expressed as percentage of total energy expenditure (EE) before and during the infusion of a lipid heparin mixture in 13 obese and 11 lean men. Values are mean \pm s.e.m. Repeated measurements ANOVA for treatment; ${ }^{\#} P<0.05,{ }^{* \# \#} P<0.001$.

During lipid heparin infusion, lipid oxidation increased and carbohydrate oxidation decreased similarly in both groups (Figure 2).

Baseline plasma insulin levels were significantly higher in obese compared to lean men, but did not change during lipid heparin infusion in both groups (Table 3 ). Plasma $\beta$-hy- droxybutyrate concentrations were similar at baseline and significantly increased $(P<0.001)$ during lipid heparin infusion. However, the increase was significantly reduced in obese compared to lean men ( $\Delta \beta$-hydroxybutyrate: $55 \pm 26$ vs $163 \pm 31 \mu \mathrm{mol} / \mathrm{l}, P<0.05$, Table 3 ). Plasma noradrenaline and adrenaline concentrations did not differ significantly

Table 3 Plasma insulin, $\beta$-hydroxybutyrate, noradrenaline and adrenaline and concentrations at rest and during lipid heparin infusion in lean and obese men

\begin{tabular}{|c|c|c|c|c|c|c|}
\hline Parameter & Baseline & $\begin{array}{c}4.9 \mu \mathrm{ll} \\
\mathrm{kgFFM} \cdot \min \end{array}$ & $\begin{array}{c}9.8 \mu \mathrm{l} / \\
\mathrm{kgFM}_{\mathrm{FF}} \cdot \mathrm{min}\end{array}$ & $\begin{array}{c}19.6 \mu \mathrm{l} / \\
\mathrm{kg}_{F F M} \cdot \min \end{array}$ & $\begin{array}{l}\text { ANOVA for } \\
\text { treatment }\end{array}$ & $\begin{array}{l}\text { ANOVA for } \\
\text { group } \times \text { treatment }\end{array}$ \\
\hline Insulin $(m U / 1)$ & & & & & NS & NS \\
\hline Obese & $19.4 \pm 3.5$ & $19.0 \pm 3.2$ & $19.3 \pm 3.3$ & $19.7 \pm 3.7$ & & \\
\hline Lean & $7.2 \pm 0.8$ & $7.2 \pm 0.9$ & $7.0 \pm 0.8$ & $6.9 \pm 0.7$ & & \\
\hline$\beta$-Hydroxybutyrate $(\mu \mathrm{mol} / \mathrm{l})$ & & & & & $P<0.001$ & $\mathrm{P}<0.5$ \\
\hline Obese & $104 \pm 12$ & $96 \pm 35$ & $98 \pm 22$ & $150 \pm 34^{*}$ & & \\
\hline Lean & $113 \pm 20$ & $140 \pm 26$ & $174 \pm 35$ & $277 \pm 43$ & & \\
\hline Noradrenaline $(\mathrm{nmol} / \mathrm{l})$ & & & & & $P<0.01$ & NS \\
\hline Obese & $2.26 \pm 0.24$ & $2.03 \pm 0.23$ & $2.00 \pm 0.29$ & $1.90 \pm 0.25$ & & \\
\hline Lean & $2.09 \pm 0.22$ & $1.91 \pm 0.16$ & $1.90 \pm 0.19$ & $1.79 \pm 0.21$ & & \\
\hline Adrenaline (nmol/l) & & & & & NS & NS \\
\hline Obese & $0.21 \pm 0.02$ & $0.18 \pm 0.02$ & $0.18 \pm 0.02$ & $0.19 \pm 0.02$ & & \\
\hline Lean & $0.28 \pm 0.04$ & $0.31 \pm 0.05$ & $0.30 \pm 0.04$ & $0.30 \pm 0.04$ & & \\
\hline
\end{tabular}

Results are mean \pm s.e.m. for 11 obese and 13 lean men. Unpaired t-test: $* p<0.05$ abese vs lean. 
between groups at baseline. During lipid heparin infusion, plasma noradrenaline levels significantly decreased $(P<0.01)$ and plasma adrenaline levels were unchanged in both groups (Table 3 ).

\section{Discussion}

The aim of the present study was to determine whether a certain increase in plasma FFA levels leads to similar increases in lipid oxidation and energy expenditure in obese and lean men. Plasma FFA levels were raised by infusing a lipid heparin mixture. Heparin was added to promote lipoprotein lipase activity and thus induce the hydrolysis of endogenous and exogenous triglycerides to FFA and glycerol. The increases in plasma FFA concentrations were similar in obese and lean men. Furthermore, the increases in lipid oxidation and thermogenesis were comparable between groups. Therefore, these data suggest that obese and lean men similarly increase their lipid oxidation and thermogenesis rates in response to a certain increase in plasma FFA levels.

The increase in energy expenditure during lipid heparin infusion in our study was comparable with that found by Thiebaud et $a l^{23}$ in lean men. Jung et $a l^{24}$ examined both obese and lean subjects, who received an i.v. bolus of heparin with or without concomitant lipid infusion, but no two subjects received the same amount of lipids. No difference was found in the response between obese and lean subjects plotting the increase in FFA level against the increase in energy expenditure, which is in accordance with our data. In contrast, Kjekshus et al ${ }^{25}$ found no changes in $\mathrm{O}_{2}$ consumption, and thus in thermogenesis, during lipid heparin infusion. However, this could be due to methodological problems, since $\mathrm{O}_{2}$ consumption was calculated from $\mathrm{CO}_{2}$ output and volumetric changes produced by respiration. Our increase in lipid oxidation after a certain increase in plasma FFA levels was comparable with the findings of Kleiber $e t a l^{26}$ in lean subjects and Golay et $a l^{27}$ in obese subjects.

In order to exclude the possibility that increased SNS activity rather than increased FFA concentration induced the increases in energy expenditure and lipid oxidation, plasma noradrenaline and adrenaline levels were measured. Plasma adrenaline levels did not change and plasma noradrenaline levels even slightly decreased during lipid heparin infusion in both groups. This is in accordance with the findings of Jung et al, ${ }^{24}$ who reached much higher plasma FFA concentrations in his experiment. This suggests that no additional SNS stimulation occurred during these tests. Plasma insulin levels, which inhibit FFA release from adipose tissue, changed neither in obese nor in lean men during lipid heparin infusion, which is in accordance with the findings of Thiebaud et $a l^{23}$ The increase in energy expenditure and lipid oxidation is therefore likely to be induced directly by the increased FFA availability. Furthermore, a recent study from our laboratory showed that inhibition of lipolysis, and thus a lower plasma FFA availability, was accompanied by a smaller increase in energy expenditure and lipid oxidation during $\beta_{1}$-adrenoceptor stimulation. ${ }^{28}$ This suggests that FFA availability may be a limiting factor for increasing lipid oxidation and energy expenditure.

An increase in plasma FFA levels does not only lead to increases in lipid oxidation and thermogenesis, but also to an increase in ketone body production in the liver. Furthermore, elevated plasma insulin concentrations seem to restrain FFA-induced ketogenesis, ${ }^{29}$ This is in line with our findings, showing that elevated insulin concentrations in the obese were associated with a smaller increase in plasma $\beta$ hydroxybutyrate concentrations during lipid heparin infusion. Using the data of Keller et al, ${ }^{29}$ it can be calculated that total lipid oxidation rates might be overestimated by $\sim 30 \%$ if $\mathrm{O}_{2}$ consumption is not corrected for the amount of $\mathrm{O}_{2}$ needed for ketone body production. In our study, the increases in plasma $\beta$-hydroxybutyrate concentration were used to estimate the increases in ketone body production during lipid heparin infusion. It was found that the increase in lipid oxidation corrected for ketone body production did not significantly differ from that without correction in both groups. The larger increase in plasma $\beta$-hydroxybutyrate concentration in the lean therefore did not confound their increase in lipid oxidation, which remained comparable with that in the obese.

In this study, a certain raise in plasma FFA levels was accompanied by similar raises in lipid oxidation and thermogenesis in obese and lean men. Comparable results were found in a study in which we infused the selective $\beta_{1}$ adrenoceptor agonist dobutamine. In this study, obese and lean men showed similar increases in plasma FFA levels, lipid oxidation and energy expenditure in response to dobutamine. ${ }^{30}$ Both studies suggest that obese men are capable of increasing their lipid oxidation and energy expenditure rates to the same extent as their lean counterparts. Furthermore, they provide no evidence for a difference in oxidative capacity in skeletal muscle between obese and lean subjects. The reduced increase in lipid oxidation in obese men during nonselective $\beta$-adrenergic stimulation, as found by Blaak et al, ${ }^{10}$ or during selective $\beta_{2}$-adrenergic stimulation, as found by Schiffelers $e t a l,{ }^{31}$ might therefore be explained by a reduced increase in plasma FFA concentration.

In conclusion, these data suggest that a certain increase in plasma FFA concentration leads to similar increases in energy expenditure and lipid oxidation in obese and lean men. The accumulation of fat in obese subjects may therefore be more likely to be due to a defect in adipose tissue lipolysis than a defect in lipid oxidation.

\section{Acknowledgements}

The authors wish to thank Joan Senden and Jos Stegen for their technical support during analysis of the blood samples. This study was supported by a grant from the Netherlands Organisation for Scientific Research (NWO), grant 903-39138. 
References

1 De Jonge l., Garrel DR. Role of the autonomic nervous system in the thermogenic response to food in lean individuals. Am / Physiol 1997; 272: E775-780.

2 Astrup AV, Christensen NJ, Simonsen L, Bülow J. Effects of nutrient intake on sympathoadrenal activity and thermogenic mechanisms. I Neurosci Meth 1990; 34: 187-192.

3 Welle S. Sympathetic nervous system response to intake. Am I Clin Nutr 1995; 62: 1118S-1122S.

4 Thorne $A$, Wahren J. $\beta$-Adrenergic btockade does not influence the thermogenic response to a mixed meal in man. Clin Physiol 1989; 9: $321-332$.

5 Astrup A, Simonsen L, Bülow J, Madsen J, Christensen NJ. Epinephtine mediates facultative carbohydrate-induced thermogenesis in human skeletal muscle. Am J Physiol 1989; 257: E340345 .

6 Blaak EE, van Baak MA, Kempen KP, Saris WHM. Role of $x$ - and $\beta$ adrenoceptors in sympathetically mediated thermogenesis. $\mathrm{Am}$ ) lowsial 1993; 264: E11-17.

7 Graen CJ, Frazer RS, Underhill S, Maycock P, Fairhurst JA, Campbell IT. Metabolic effects of dobutamine in normal man. Clin Sci $1992 ; 82: 77-83$

8 Schiffelers SLH, Van Harmelen VJA, De Grauw HAJ, Saris WHM, Van Baak MA. Dobutamine as selective $\beta_{1}$-adrenoceptor agonist in in vivo studies on human thermogenesis and lipid utilization. I Appl Plysiol 1999; 87: 977-981.

9 Simonsen L, Stallknecht B, Bülow J. Contribution of skeletal muscle and adipose tissue to adrenaline-induced thermogenesis in man. Int / Obes Relat Metab Disord 1993; 17(Suppl): S47-51.

10 Blaak EE, van Baak MA, Kemerink GJ, Pakbiers MT, Heidendal GA, Saris WH. p-Adrenergic stimulation of energy expenditure and forearm skeletal muscle metabolism in lean and obese men. $A m$ Plysiol 1994; 267: E306-315.

11 Liggett SB, Shah SD, Cryer PE. Characterization of $\beta$-adrenergic receptors of human skeletal muscle obtained by needle biopsy. Ain J physiol 1988; 254: E795-798.

12 De Jonge L, Bray GA. The thermic effect of food and obesity: a critical review. Obes Res 1997; 5: 622-631.

13 Jung RT, Shetty PS, James WPT, Barrand $M$, Callingham $M$. Reduced thermogenesis in obesity. Nature 1979; 279: 322-323.

14 Blaak EE, van Baak MA, Kester AD, Saris WH. $\beta$-Adrenergically mediated thermogenic and heart rate responses: effect of obesity and weight loss. Metabolism 1995; 44: 520-524.

15 Colberg SR, Simoneau JA, Thaete FL, Kelley DE. Skeletal muscle utilization of free fatty acids in women with visceral obesity. I Clin Invest 1995; 95: 1846-1853.

16 Simoneau JA, Colberg SR, Thaete FL, Kelley DE. Skeletal muscle glycolytic and oxidative enzyme capacities are determinants of insulin sensitivity and muscle composition in obese women. FASEB J 1995; 9: 273-278.
17 Siri WE. The gross composition of the body. Adv Biol Med Physiol $1956 ; 4: 239-280$

18 Weir JB. New methods for calculating metabolic rate with special reference to protein metabolism. / Physiol 1949; 109: 1-9.

19 Ferrannini $\mathrm{E}$. The theoretical bases of indirect calorimetry: a review. Metnbolism 1988; 37: $287-301$.

20 Moore JJ, Marcus M, Sax SM. Kinetic assay of $\beta$-hydroxybutyrate in plasma with COBAS BIO centrifugal analyzer. Clin Chem 1982; 73: $1334-1339$

21 Smedes I, Kraak JC, Poppe $H$. Simple and fast solvent extraction system for selective and quantitative isolation of adrenaline, noradrenaline and dopamine from plasma and urine. I Chromntogr $1982 ; 231: 25-39$.

22 Ravussin E, Bogardus C. Relationship of genetics, age, and physical fitness to daily energy expenditure and fuel utilization. Am I Clin Nutr 1989; 49: 968-975.

23 Thiebaud D, Acheson K, Schutz Y, Felber JP, Golay A, DeFronzo RA et al. Stimulation of thermogenesis in men after combined glucose-long-chain triglyceride infusion. Am J Clin Nutr 1983; 37: $603-611$.

24 Jung RT, Shetty PS, James WP. Heparin, free fatty acids and an increased metabolic demand for oxygen. l'astgrad Med J 1980; 56: $330-332$.

25 Kjekshus JK, Ellekjaet E, Rinde P. The effect of free fatty acids on oxygen consumption in man: the free fatty acid hypothesis. Scand J Clin Lab Invest 1980; 40: 63-70.

26 Kleiber H, Munger R, Jallut D, Tappy L, Felley C, Golay A et al. Interaction of lipid and carbohydrate metabolism after infusions of lipids or lipid lowering agents; lack of a direct relationship between free fatty acid concentrations and glucose disposal. Diabete \& Mctnb 1992; 18: 84-90.

27 Golay A, Felber JP, Jallut D, Munger R, Ruiz J, Jéquier E. Effect of lipid oxidation on the regulation of glucose utilization in obese patients. Acta Diabetol 1995; 32: 44-48.

28 Schiffelers SLH, Brouwer EMC, Saris WHM, Van Baak MA, Inhibi-

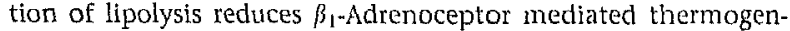
esis in man. Metabolism 1998; 47: 1462-1467.

29 Keller U, Gerber P, Stauffacher W. Fatty acid-independent inhibition of hepatic ketone body production by insulin in humans. An J Physiol 1988; 254: E694-699.

30 Schiffelers SLH, Van Baak MA, Saris WHM. $\beta_{1}$-Adrenoceptor mediated thermogenesis in lean and obese men. (Abstract.) Int I Obes Relat Metab Disord 1997; 21 (Suppl): S59.

31 Schiffelers SLH, Saris WHM, Van Baak MA. $\beta_{2}$-adrenoceptor mediated lipolysis and fat oxidation are reduced in obese men. (Abstract.) Int / Obes Relat Metab Disord 1998; 22(Suppl): S75. 